\title{
Introduction to the special issue on the biology of the circumpolar flaw lead (CFL) in the Amundsen Gulf of the Beaufort Sea (Arctic Ocean)
}

\author{
Jody W. Deming $\cdot$ Louis Fortier
}

Published online: 8 November 2011

(C) Springer-Verlag 2011

\begin{abstract}
The sea-ice cover of the Arctic Ocean is decreasing in areal extent and volume more rapidly than model predictions of its response to continued warming of earth's lower atmosphere. Reflecting this decrease is the spatial and temporal widening of the circumpolar flaw lead, a zone of open water and unconsolidated ice along the coastlines of the shallow seas that surround the deep Arctic Ocean basins. As part of the International Polar Year, the Circumpolar Flaw Lead System Study deployed the research icebreaker Amundsen from October 2007 to August 2008 in the flaw lead segment bordering Banks Island in the Canadian Beaufort Sea. With participation from Canada, the USA, Spain, Germany, China, Russia, the UK, Norway, Belgium, the Netherlands, France, and Sweden, the multi-disciplinary overwintering expedition logged 9,812 scientist-days in an effort to decipher key aspects of the ecosystem of the flaw lead. Highlights of the scientific achievements documented in this special issue on the biology of the circumpolar flaw lead system help to capture the depth, breadth, and novelty of this remarkable exploration.
\end{abstract}

Keywords Flaw lead $\cdot$ Sea ice $\cdot$ Arctic ecosystem

J. W. Deming $(\bowtie)$

School of Oceanography, University of Washington,

Seattle, WA 98195, USA

e-mail: jdeming@u.washington.edu

L. Fortier

ArcticNet and Québec-Océan, Université Laval,

Quebec, QC G1V 0A6, Canada

\section{Introduction and rationale}

Despite the patchiness of the geological record, the available evidence indicates that sea ice has covered at least part of the Arctic Ocean consistently over the last 13-14 million years (Polyak et al. 2010). Since the mid twentieth century, the areal extent of the ice has been diminishing (Kinnard et al. 2008), with precipitous drops in the multi-year ice of the perennial pack of the central Arctic basin in recent years (Rigor and Wallace 2004; Nghiem et al. 2007). Until the 1950s, sea ice covered circa 8 million $\mathrm{km}^{2}$ of the Arctic Ocean at its annual minimum in September. By 2007, it had reached an unprecedented low of 4.3 million $\mathrm{km}^{2}$ (Comiso et al. 2008; Stroeve et al. 2008). The most recently completed evaluation of a September minimum indicated the nearly equivalent low of 4.6 million $\mathrm{km}^{2}$ in 2011 (according to satellite-based data presented by the US National Snow and Ice Data Center; http://nsidc.org/arcticseaicenews/).

The recent changes in sea-ice volume, considered more sensitive to climate warming than ice extent (Zhang et al. 2010), provide a similar, if not more dramatic, picture of the ongoing loss of sea ice in the Arctic Ocean. Determining sea-ice volume is a greater challenge than sea-ice extent. That challenge is currently met by the Pan-Arctic Ice Ocean Modeling and Assimilation System (PIOMAS; http://psc.apl.washington.edu/ArcticSeaiceVolume/IceVolume.php) that incorporates ice, ocean, and atmosphere data to estimate sea-ice volume. The latest evaluations using PIOMAS show a statistically significant basis for claiming a new record low for arctic sea-ice volume in the year 2011 (Schweiger et al. 2011).

Some conclusions appear inescapable: (1) arctic sea-ice extent and volume continue to drop; (2) significant recovery from the previous record lows of 2007 is not imminent; and (3) a summer ice-free Arctic Ocean within the coming 
decade is a viable scenario. Although the Arctic Ocean is expected to freeze over again each winter for many decades to come (Zhang et al. 2010), the ever-expanding summer season of open water represents a major environmental challenge for organisms and ecosystems currently adapted to an ice covered ocean. Based on present differences between arctic and boreal biota, the shift from a permanent to entirely seasonal sea-ice cover will necessarily alter prevailing ecosystems and ecosystem services of the Arctic Ocean. The first demonstrable biological changes can be expected as the peripheral zones of the Arctic Ocean take on new ice characteristics, including earlier spring ice melt and delayed autumn freeze-up.

The periphery of the Arctic Ocean is currently characterized by the circumpolar flaw lead, which corresponds to an area of unconsolidated ice or ice-free waters between the mobile central ice pack and the fixed landfast ice. ("Flaw" derives from the Scandinavian "flew" for a coastal breeze, referring to the role of this wind in creating the flaw lead.) The circumpolar flaw lead runs parallel to the coast in all the shallow ancillary seas of the Arctic Ocean, including Hudson Bay (Barber and Massom 2007). In some areas, it widens considerably in spring and summer to form recurrent polynyas where biological productivity is often greatly enhanced, as in the North Water of northern Baffin Bay (Deming et al. 2002; http:// www.aina.ucalgary.ca/arcticnet). With the progressive demise of the perennial ice cover and the resulting lengthening of the ice-free season over the shallow shelves of the Arctic Ocean, the flaw lead is expected to enlarge and its seasonal duration to lengthen. Hence, to some extent, the circumpolar flaw lead may be seen as the embryo of a future seasonally ice-free Arctic Ocean. Studying the present circum-annual processes that link sea-ice dynamics to biological productivity, biogeochemical cycling and ecosystem services in the flaw lead will likely provide invaluable insights into the response of arctic marine ecosystems to climate warming and reductions in sea-ice extent and volume.

Over the annual cycle in 2003-2004, the international Canadian Arctic Shelf Exchange Study (CASES, 20022007) documented the inshore ecosystem of the Mackenzie Shelf of the Beaufort Sea, including the unexplored winter ecology of Franklin Bay where the Canadian Coast Guard Ship (CCGS) Amundsen was immobilized in the landfast ice cover for the winter (Fortier and Cochran 2008). During CASES, regular surveys of the offshore ice field by helicopter and fixed-wing aircrafts suggested that a medium-sized icebreaker such as the Amundsen could remain mobile in the flaw lead in winter against the prevailing east-west drift of the ice pack. The possibility of studying the offshore ecosystem of the Beaufort Sea over an annual cycle was highly motivating; the International Polar Year (IPY) 2007-2009 provided the unique opportunity and financial means to undertake this bold plan.

As part of the Canadian contribution to the IPY, the Circumpolar Flaw Lead System Study (CFL) deployed the Amundsen from October 2007 to August 2008 in the flaw lead segment bordering Banks Island in the Canadian Beaufort Sea. A detailed description of the research objectives, the extensive multi-national participation in CFL, and the physical setting for the entire study has been provided by Barber et al. (2010). A central CFL objective, however, was to evaluate the annual cycle of the offshore ecosystem in response to the forcing of the light, wind, and nutrient regimes by sea ice, comparing key biological processes inside and outside the flaw lead over the seasons. This special issue of Polar Biology assembles many of the first contributions toward this larger goal.

\section{Probing the flaw lead ecosystem}

No single special issue could encompass the full probing of the flaw lead ecosystem accomplished during CFL. Some papers have already appeared in other journals and many more will emerge as final data sets are analyzed and synthesized together with others (e.g., Forest et al. 2011a, b). In this issue, each piece of work was prepared to be self-sufficient, with project-specific sampling maps and publication dates (to appear on-line without delay), yet when read together they reflect a much greater whole than even the sum of single studies may convey. By highlighting some of the scientific achievements featured herein, we attempt to capture the depth, breadth and novelty of the CFL exploration.

Highlights for the sympagic (sea-ice) ecosystem:

- CFL allowed for unique evaluations of protist assemblages in winter sea ice, which revealed lower abundance levels but similar diversity to spring sea ice, implying that the timing of autumn freeze-up critically determines the players available for the spring ice-algal bloom (Niemi et al. (2011, this special issue) on "Protist assemblages in winter sea ice: setting the stage for the spring ice algal bloom").

- The delayed autumn freeze-up at the start of CFL yielded new sea ice that contained higher concentrations of free DNA than any other marine environment, highlighting both the stress to organisms of freezing in and the potential to gain new traits via horizontal gene transfer once in the ice (Collins and Deming (2011a, this special issue) on "Abundant dissolved genetic material in Arctic sea ice, Part I: Extracellular DNA").

- That same new sea ice also yielded exceptionally high ratios and contact rates of viruses to bacteria, signifying 
the possible costs (bacterial mortality) and benefits (selection for ice adaptation, enhanced conditions for horizontal gene transfer) to freezing into the ice (Collins and Deming (2011b, this special issue) on "Abundant dissolved genetic material in Arctic sea ice, Part II: Viral dynamics during autumn freeze-up").

- The heterotrophic bacterial carbon demand for growth in spring and summer sea ice has long been known to be important in sympagic ecosystems, but only during CFL was the unknown status of bacterial respiration in sea ice finally addressed, yielding evidence that respiration is a dominant carbon sink critical to future evaluations of the Arctic ice cover as a $\mathrm{CO}_{2}$ transporter (Nguyen and Maranger (2011, this special issue) on "Respiration and bacterial carbon dynamics in Arctic sea ice").

- As winter gave way to spring, a study of ice-algal proxies revealed the power of a diatom-specific biomarker to track the temporal extent of the bottom sea-ice bloom, with the promise of its utility to contemporary benthic ecosystem studies and to paleooceanographic assessments of former climate impacts on primary production in sea ice (Brown et al. (2011, this special issue) on "Temporal and vertical variations of lipid biomarkers during a bottom ice diatom bloom in the Canadian Beaufort Sea: further evidence for the use of the IP25 biomarker as a proxy for spring Arctic sea ice").

- As spring gave way to summer and advanced ice melt, the ice-algal community diverged spatially and taxonomically, with flagellates seeding the underlying waters and high-light adapted diatoms remaining in the interior of the ice (Mundy et al. (2011, this special issue) on "Characteristics of two distinct high-light acclimated algal communities during advanced stages of sea ice melt").

- Ultimately, sea ice in this region was discovered to be a richer breeding ground for higher trophic levels (meiofauna) than previously expected, with newly detected species occurring in the ice and not always confined to the bottom algal-rich layer (Marquardt et al. (2011, this special issue) on "Vertical distribution of sympagic meiofauna in sea ice in the Canadian Beaufort Sea").

Highlights for the pelagic ecosystem:

- During the course of the spring bloom in the open waters of the flaw lead system, phylogenetic and functional analyses of the protist communities in shallow surface waters suggested strong shifts in the dominant primary producers, with heterotrophic protists coming to the fore by the end of the season (Terrado et al. (2011, this special issue) on "Protist community composition during spring in an Arctic flaw lead polynya").

- An unusual temporal evaluation of photosynthetic parameters within a subsurface chlorophyll maximum as it formed and deepened revealed continuous adaptation by the phytoplankton to changing light levels and nutrient inputs, boding well for enhanced primary production as upwelling events become more common on icereduced Arctic shelves (Palmer et al. (2011, this special issue) on "Spatial and temporal variation of photosynthetic parameters in natural phytoplankton assemblages in the Beaufort Sea, Canadian Arctic").

- The dominant net zooplankton in the region had not reached adulthood during the winter of 2008 , as in the past, and thus suffered low recruitment later in the year as egg production and development fell out of sync with the peak algal bloom that also came earlier than usual due to early ice break-up (Wold et al. (2011, this special issue) on "Life strategy and diet of Calanus glacialis during the winter-spring transition in Amundsen Gulf, southeastern Beaufort Sea").

- The CFL opportunity for under-ice diving operations, however, detected a zooplankton boom just below the ice during the melting season, fueled by the release of ice algae (Hop et al. (2011, this special issue) on "Zooplankton boom and ice amphipod bust below melting sea ice in the Amundsen Gulf, Arctic Canada").

- The rare winter use of an echosounder in the Arctic revealed intense aggregations of polar cod in the deep Atlantic layer of the region as long as sea ice persisted, linking reproductive and prey-avoidance strategies to ice cover and thus suggesting a precarious future for this central player in the current ecosystem (Geoffroy et al. (2011, this special issue) on "The aggregation of polar cod (Boreogadus saida) in the deep Atlantic layer of icecovered Amundsen Gulf (Beaufort Sea) in winter").

- A valuable retrospective look at beluga whales revealed their affinity for heavy ice and deep waters, consonant with what we now know from CFL work on their polar cod prey, and led to the prediction, supported by CFL observations, that the beluga spring migration would begin earlier during an early ice break-up year (Asselin et al. (2011, this special issue) on "Beluga (Delphinapterus leucas) habitat selection in the eastern Beaufort Sea in spring, 1975-1979").

Highlights for the fluxes that link sympagic, pelagic, and benthic ecosystems:

- Although pelagic primary production was very high in the region due to early ice retreat and coastal upwelling and by summer was dominated by large cells typically expected to sink, these factors did not translate to high subeuphotic carbon export, suggesting substantial zooplankton and microbial activity in the upper waters (Sallon et al. (2011, this special issue) on "Summertime primary production and carbon export 
in the southeastern Beaufort Sea during the low ice year of 2008").

- A closer look at the microbial role in enzymatically altering particulate organics in the region provided a new and direct measure of the substantial microbial attenuation of downward particle fluxes in the region, hinting of even higher attenuation in future scenarios that favor pelagic microbial activity to the detriment of the benthos (Kel$\operatorname{logg}$ et al. (2011, this special issue) on "Evidence for microbial attenuation of particle flux in the Amundsen Gulf and Beaufort Sea: elevated hydrolytic enzyme activity on sinking aggregates").

- Despite—or perhaps because of-the strong attenuation of particulate organic fluxes to the seafloor in this region, algal blooms related to early sea-ice retreat were critical to the benthos, with the initial size of the benthic community at that time being an additional determinant of the fate of carbon at the seafloor (Link et al. (2011, this special issue) on "Spring-to-summer changes and regional variability of benthic processes in the western Canadian Arctic").

\section{The Legacy of CFL for Polar Biology}

As highlighted above, the opportunity to be present for observations and sampling through an annual cycle, from a ship kept mobile in a region where the ice cover was greatly altered from prior years in measurable ways (from late freeze-up to early break-up), allowed for discoveries at the organism and ecosystem level, resolution to some longstanding mysteries, and identification of potential organism/ecosystem problems and shifts yet to come. Whereas the CASES overwintering expedition of 2003-2004 had yielded its own discoveries and surprises, presaging those of CFL, the winter findings were restricted geographically to the relatively quiescent Franklin Bay where the ship was immobilized in fast ice. During CFL, biologists may have had to contend with the frustration of moving station targets as the ship was kept safely mobile among the many old and new ice floes, but they also benefited greatly from a wider geographical range of exploration than ever imagined for the winter season. The fact that the overwintering season immediately followed the record low for ice extent witnessed in September 2007 opened unique opportunities to gain a window into the future when a reduced ice cover, in both temporal and spatial extent and volume, becomes the new norm. Clues of possible short-term biological adaptability and even enhanced activity were detected, even as the ecosystem remained linked to the ice. The long-term future remains the challenge to predict, but CFL has provided an open door to it.

\section{References}

Asselin NC, Barber DG, Stirling I, Ferguson SH, Richard PR (2011) Beluga (Delphinapterus leucas) habitat selection in the eastern Beaufort Sea in spring, 1975 to 1979. Polar Biol. doi:10.1007/ s00300-011-0990-5

Barber DG, Massom RA (2007) The role of sea ice in Arctic and Antarctic polynyas. In: Smith WO Jr, Barber DG (eds) Polynyas: windows to the World. Elsevier Oceanography Series 74, pp 1-54

Barber DG, Asplin MG, Gratton Y, Lukovich JV, Galley RJ, Raddatz RL, Leitch D (2010) The International Polar Year (IPY) Circumpolar Flaw Lead (CFL) System Study: overview and the physical system. Atmosphere Ocean 48:225-243

Brown TA, Belt ST, Philippe B, Mundy CJ, Masse G, Poulin M, Gosselin M (2011) Temporal and vertical variations of lipid biomarkers during a bottom ice diatom bloom in the Canadian Beaufort Sea: further evidence for the use of the IP25 biomarker as a proxy for spring Arctic sea ice. Polar Biol. doi:10.1007/s00300-0100942-5

Collins RE, Deming JW (2011a) Abundant dissolved genetic material in Arctic sea ice, Part I: extracellular DNA. Polar Biol. doi:10.1007/s00300-011-1041-y

Collins RE, Deming JW (2011b) Abundant dissolved genetic material in Arctic sea ice, Part II: viral dynamics during autumn freeze-up. Polar Biol. doi: 10.1007/s00300-011-1008-z

Comiso JC, Parkinson CL, Gersten R, Stock L (2008) Accelerated decline in the Arctic sea ice cover. Geophys Res Lett 35:L01703

Deming JW, Fortier L, Fukuchi M (2002) The International North Water Polynya Study (NOW): a brief overview. Deep-Sea Res II 49:1-6

Forest A, Galindo V, Darnis G, Lalande C, Pineault S, Tremblay JE, Fortier L (2011a) Carbon biomass, elemental ratios (C:N) and stable isotopic composition $\left(\partial^{13} \mathrm{C}, \partial^{15} \mathrm{~N}\right)$ of dominant calanoid copepods during the winter-to-summer transition in the Amundsen Gulf (Arctic Ocean). J Plankton Res 33:161-178

Forest A, Tremblay JE, Gratton Y, Martin J, Gagnon J, Darnis G, Sampei M, Fortier L, Ardyna M, Gosselin M, Hattori H, Nguyen D, Maranger R, Vaque D, Marrase C, Pedros-Alio C, Sallon A, Michel C, Kellogg C, Deming J, Shadwick E, Thomas H, Link H, Archambault P, Piepenburg D (2011b) Biogenic carbon flows through the planktonic food web of the Amundsen Gulf (Arctic Ocean): a synthesis of field measurements and inverse modeling analyses. Progr Oceanogr. http://dx.doi.org/10.1016/j.pocean.2011.05.002

Fortier L, Cochran JK (2008) Introduction to special section on annual cycles on the Arctic Ocean Shelf. J Geophys Res 113:C03S00. doi: 10.1029/2007JC004457

Geoffroy M, Robert D, Darnis G, Fortier L (2011) The aggregation of polar cod (Boreogadus saida) in the deep Atlantic layer of icecovered Amundsen Gulf (Beaufort Sea) in winter. Polar Biol. doi:10.1007/s00300-011-1019-9

Hop H, Mundy CJ, Gosselin M, Rossnagel AL, Barber DG (2011) Zooplankton boom and ice amphipod bust below melting sea ice in the Amundsen Gulf, Arctic Canada. Polar Biol. doi:10.1007/ s00300-011-0991-4

Kellogg CTE, Carpenter SD, Renfro AA, Sallon A, Michel C, Cochran JK, Deming JW (2011) Evidence for microbial attenuation of particle flux in the Amundsen Gulf and Beaufort Sea: elevated hydrolytic enzyme activity on sinking aggregates. Polar Biol. doi:10.1007/s00300-011-1015-0

Kinnard C, Zdanowicz CM, Koerner R, Fisher DA (2008) A changing Arctic seasonal ice zone-observations from 1870-2003 and possible oceanographic consequences. Geophys Res Lett 35:L02507

Link H, Archambault P, Tamelander T, Renaud PE, Piepenburg D (2011) Spring-to-summer changes and regional variability of 
benthic processes in the western Canadian Arctic. Polar Biol. doi:10.1007/s00300-011-1046-6

Marquardt M, Kramer M, Carnat G, Werner I (2011) Vertical distribution of sympagic meiofauna in sea ice in the Canadian Beaufort Sea. Polar Biol. doi:10.1007/s00300-011-1078-y

Mundy CJ, Gosselin M, Ehn JK, Belzile C, Poulin M, Alou E, Roy S, Hop H, Lessard S, Papakyriakou TN, Barber DG, Stewart J (2011) Characteristics of two distinct high-light acclimated algal communities during advanced stages of sea ice melt. Polar Biol. doi:10.1007/s00300-011-0998-x

Nghiem SV, Rigor IG, Perovich DK, Clemente-Colon P, Weatherly JW, Nuemann G (2007) Rapid reduction of Arctic perennial sea ice. Geophys Res Lett 34:L19504

Nguyen D, Maranger R (2011) Respiration and bacterial carbon dynamics in Arctic sea ice. Polar Biol. doi:10.1007/s00300-0111040-z

Niemi A, Michel C, Hille K, Poulin M (2011) Protist assemblages in winter sea ice: setting the stage for the spring ice algal bloom. Polar Biol. doi:10.1007/s00300-011-1059-1

Palmer MA, Arrigo KR, Mundy CJ, Ehn JK, Gosselin M, Barber DG, Martin J, Alou E, Roy S, Tremblay J-E (2011) Spatial and temporal variation of photosynthetic parameters in natural phytoplankton assemblages in the Beaufort Sea, Canadian Arctic. Polar Biol. doi:10.1007/s00300-011-1050-x

Polyak L, Alley RB, Andrews JT, Brigham-Grette J, Cronin TM, Darby DA, Dyke AS, Fitzpatrick JJ, Funder S, Holland M, Jennings
AE, Miller GH, O'Regan M, Savelle J, Serreze M, St John K, White JWC, Wolff E (2010) History of sea ice in the Arctic. Quat Sci Rev 29:1757-1778

Rigor IG, Wallace JM (2004) Variations in the age of Arctic sea ice and summer sea ice extent. Geophys Res Lett 31:L09401

Sallon A, Michel C, Gosselin M (2011) Summertime primary production and carbon export in the southeastern Beaufort Sea during the low ice year of 2008. Polar Biol. doi:10.1007/s00300-011-1055-5

Schweiger A, Lindsay R, Zhang J, Steele M, Stern H, Kwok R (2011) Uncertainty in modeled Arctic sea ice volume. J Geophys Res 116:C00D06. doi:10.1029/2011JC007084

Stroeve JC, Serreze M, Drobot S, Gearhead S, Holland M, Maslanik JA, Meier W, Scambos T (2008) Arctic sea ice extent plummets in 2007. Eos Trans Amer Geophys Union 89:13-14

Terrado R, Medrinal E, Dasilva C, Thaler M, Vincent W, Lovejoy C (2011) Protist community composition during spring in an Arctic flaw lead polynya. Polar Biol. doi:10.1007/s00300-011-1039-5

Wold A, Darnis G, Søreide JE, Leu E, Philippe B, Fortier L, Poulin M, Kattner G, Graeve M, Falk-Petersen S (2011) Life strategy and diet of Calanus glacialis during the winter-spring transition in Amundsen Gulf, southeastern Beaufort Sea. Polar Biol. doi:10.1007/s00300-011-1062-6

Zhang J, Steele M, Schweiger A (2010) Arctic sea ice response to atmospheric forcings with varying levels of anthropogenic warming and climate variability. Geophys Res Lett 37:L20505 